\title{
Development of poly(vinyl alcohol)-based membranes by the response surface methodology for environmental applications
}

\author{
Desenvolvimento de uma membrana de poli (vinil álcool) via análise de \\ superfícies de resposta para aplicações ambientais
}

\author{
Juliana Zanol Merck' \\ Camila Suliani Raota" \\ Jocelei Duarte"II \\ Camila Baldasso'v \\ Janaina da Silva Crespov \\ Marcelo Giovanelavı
}

\begin{abstract}
The pollution of hydric sources by pharmaceuticals is an issue in many countries, particularly in Brazil. The presence of these substances causes deleterious effects on the environment and human health. One of the main sources of this contamination is domestic sewage, due to the expressive amount of medicines released in their unaltered form. Unfortunately, traditional wastewater treatment is not effective for the removal of pharmaceuticals and, for this reason, membrane technology is an attractive alternative to overcome this issue. In this regard, hydrophilic polymers, such as poly(vinyl alcohol) (PVA), are the most suitable. However, their high affinity with water causes intense swelling, leading to severe modifications in the membrane properties. In view of all these facts, the present work evaluated the swelling of PVA-based membranes, with the aim of finding the membrane preparation method that has the lowest swelling, thereby providing the most suitable characteristics for pharmaceutical removal from wastewater. The membranes were prepared by the casting of a polymeric solution, with PVA as a basis polymer, citric acid as a crosslink agent and glycerol and silver nanoparticles as performance additives. The process optimization was performed using a design of experiments with posterior analysis by the response surface methodology (RSM). The RSM assessed the effect on the membrane swelling of the factors, including citric acid concentration and the time and temperature of crosslinking. The membrane characterization was performed by Fourier-transform infrared (FT-IR) spectroscopy, scanning electron microscopy coupled with a field emission gun (SEM-FEG) and water contact angle (WCA) measurements. Overall, the condition that showed the lowest swelling was obtained with $10 \%$ of citric acid and crosslinking for $4 \mathrm{~h}$ at $130{ }^{\circ} \mathrm{C}$. Under these conditions, the membrane had a mass swelling of $42 \%$ and a dimensional swelling of $24 \%$. Additionally, the statistical analysis revealed that the factors with the dominant effects were the citric acid concentration and the temperature of crosslinking. The FT-IR analysis suggested that the crosslinking occurred by an esterification reaction, as showed by the stretching frequencies of $\mathrm{C}=\mathrm{O}$ at $1710 \mathrm{~cm}^{-1}$ and ester $\mathrm{C}-\mathrm{O}$ at $1230 \mathrm{~cm}^{-1}$. Moreover, the SEM-FEG images revealed a smooth and flat surface and a dense cross section with a thickness of $\sim 113 \mu \mathrm{m}$. Concerning the WCA, the angle was at $\sim 80^{\circ}$, which is characteristic of hydrophilic materials. Finally, the data suggested that it is possible to optimize the
\end{abstract}


membrane preparation process with adequate properties so that it can be subsequently applied to the removal of pharmaceuticals from hospital wastewater.

Keywords: Poly(vinyl alcohol); Design of experiments; Response surface methodology; Membranes; Characterization.

\section{Resumo}

A contaminação dos corpos hídricos por fármacos está sendo observada em diversos países, especialmente no Brasil. A presença dessas substâncias provoca efeitos nocivos, tanto ao meio ambiente quanto à saúde dos seres humanos. O esgoto doméstico é a principal fonte dessa contaminação, uma vez que uma grande quantidade de fármacos ingeridos pelo homem é excretada na sua forma inalterada. Infelizmente, o tratamento convencional de efluentes é pouco eficiente na remoção dessas substâncias e, nesse sentido, uma alternativa é processo de separação por membranas (PSM). Para essa aplicação, os polímeros hidrofílicos, como o poli(vinil álcool) (PVA), são os materiais mais apropriados. Entretanto, essa característica faz com que as membranas de PVA sofram um inchamento intenso quando em contato com a água, o que altera propriedades importantes para os PSM. Nesse contexto, o presente trabalho teve por objetivo avaliar o inchamento de membranas de PVA, a fim de determinar o método de preparação que proporciona o menor inchamento, fornecendo as características mais adequadas para a remoção de fármacos de efluentes. As membranas foram preparadas pelo espalhamento de uma solução polimérica contendo PVA como polímero base, ácido cítrico como agente reticulante, e glicerol e nanopartículas de prata como aditivos de performance. A otimização do processo foi realizada por meio de um planejamento experimental com posterior análise de superfícies de resposta, avaliando-se a influência da concentração de agente reticulante, além do tempo e da temperatura de reticulação no inchamento da membrana. As membranas foram ainda caracterizadas por meio das técnicas de espectroscopia de infravermelho com transformada de Fourier (FT-IR), microscopia eletrônica de varredura com emissão de campo (MEV-FEG) e ângulo de contato com água (WCA). A condição de melhor desempenho foi obtida utilizando-se $10 \%$ de ácido cítrico e reticulação por $4 \mathrm{~h}$ a $130^{\circ} \mathrm{C}$. Nessas condições, a membrana teve um inchamento mássico de $42 \%$ e dimensional de $24 \%$. Também se verificou que a concentração do ácido cítrico e a temperatura de reticulação foram os fatores de maior influência, de acordo com a análise estatística. De modo geral, a análise de FT-IR indicou a reticulação da membrana por meio de uma reação de esterificação, evidenciada pelos estiramentos das ligações $C=O$ em $1710 \mathrm{~cm}^{-1}$ e de $C-O$ de ésteres em $1230 \mathrm{~cm}^{-1}$. As imagens de MEV-FEG, por sua vez, revelaram uma superfície lisa e plana, além de uma secção transversal densa com aproximadamente $113 \mu \mathrm{m}$ de espessura. $\mathrm{O}$ ângulo de contato foi de aproximadamente $80^{\circ}$, típico de materiais de caráter hidrofílico. Finalmente, o conjunto de dados evidenciou que foi possível aperfeiçoar a preparação de uma membrana com características adequadas para a subsequente aplicação na remoção de fármacos de efluentes hospitalares.

Palavras-Chave: Poli(vinil álcool); Planejamento experimental; Superfície de resposta; Membranas; Caracterização. 


\section{Introduction}

Water pollution by pharmaceutical residues has attracted the attention of many researchers due to the deleterious effects they can have on the environment and human health (VERAS et al., 2019). The behavior of these substances, their metabolites and their synergic action on hydric systems is not yet completely understood. However, several studies point to their noxious consequences (MIAROV; TAL; AVISAR, 2020). The pharmaceuticals present in aquatic environments, for example, have a negative influence on fish physiology and comportment (VERAS et al., 2019).

The main source of water pollution is domestic sewage because of the expressive concentration of pharmaceuticals released in their unaltered form. According to the Organization for Economic Cooperation and Development (OECD, 2019), between 30\% and $90 \%$ of the oral pharmaceuticals are expelled as active substances. Therefore, these substances became persistent in aquatic environments due to their stability and durability (OLIVEIRA et al., 2020). In Brazil, a review performed by Montagner et al. (2019) evaluated the occurrence of pharmaceuticals in water bodies in São Paulo state for ten years. The study detected 25 medicines in wastewater, surface water, groundwater and drinking water.

Unfortunately, traditional wastewater treatment is not efficient for the removal of these substances due to the physicochemical diversity of the compounds and the complexity of the residue matrix (VIOTTI et al., 2019). In this context, an attractive alternative for the mitigation of pharmaceuticals impact is membrane technology. Studies have been made to analyze the performance of several polymeric materials on the removal of pharmaceuticals. Raicopol et al. (2019), for example, used a cellulose acetate membrane loaded with magnesium and aluminum oxides for the removal of sodium diclofenac (SD) and tetracycline (TC). The composite membrane was able to remove $21 \%$ of SD and $17 \%$ of TC. A polyethersulfone ultrafiltration membrane was modified with polydopamine and quaternate chitosan by Ouyang et al. (2019). The membrane was successfully applied in the removal of atenolol, carbamazepine, and ibuprofen, with rejection rates of $81.67 \%, 92.50 \%$, and $89.85 \%$, respectively. Nadour et al. (2019) synthesized a polysulfone (PSf)- 
methylcellulose (MC) membrane with powdered activated carbon (PAC). The PSf-MC/PAC membrane was able to remove $34 \%$ of paracetamol and $28 \%$ of metronidazole from water.

Poly(vinyl alcohol) (PVA) is a highly hydrophilic synthetic polymer, which acts as an adequate material for water treatment by membranes. However, this quality means that PVA membranes have an intense swelling when in contact with water, thereby changing important properties of the process (BOLTO et al., 2009). The high swelling promotes the distancing of the polymer chains, allowing the passage of water. This phenomenon increases the water flux and reduces the selectivity of the process (PRAPTOWIDODO, 2005). Thus, the PVA membrane crosslinking is required for the reduction of the hydrophilicity and the improvement of the selectivity.

PVA-based membranes have been reported in the literature for several purposes. Bojnourd and Pakizeh (2018) coated a PSf membrane with PVA and montmorillonite, and the composite membrane showed $92.99 \%$ of sodium chloride rejection and $98.8 \%$ of cephalexin rejection. Mansor et al. (2020) prepared a blended membrane of PVA and cellulose acetate using the phase inversion method, and the membrane presented $99.9 \%$ removal of crystal violet. Guo et al. (2019) coated a PSf membrane with a gradient crosslinked PVA layer and the membrane was able to reject $38.2 \%$ of sodium chloride and $90.7 \%$ of sodium sulfate. However, more research is needed for the application of PVAbased membranes in environmental remediation.

Through the study of crosslinking parameters, it is possible to determine the best conditions to reach the characteristics suitable for PVA membrane applications. PVA crosslinking can be achieved through physical and chemical methods. Among them, the use of crosslinking agents, such as carboxylic acids, is one of the most common chemical methods (HOSSEINZADEH, 2013). In this case, crosslinking occurs by an esterification reaction, where free hydroxyls from PVA substitute the carbonyls from the carboxylic groups (PANG et al., 2011), as shown in Figure 1. 
Figure 1 - Schematic representation of PVA crosslinking reaction

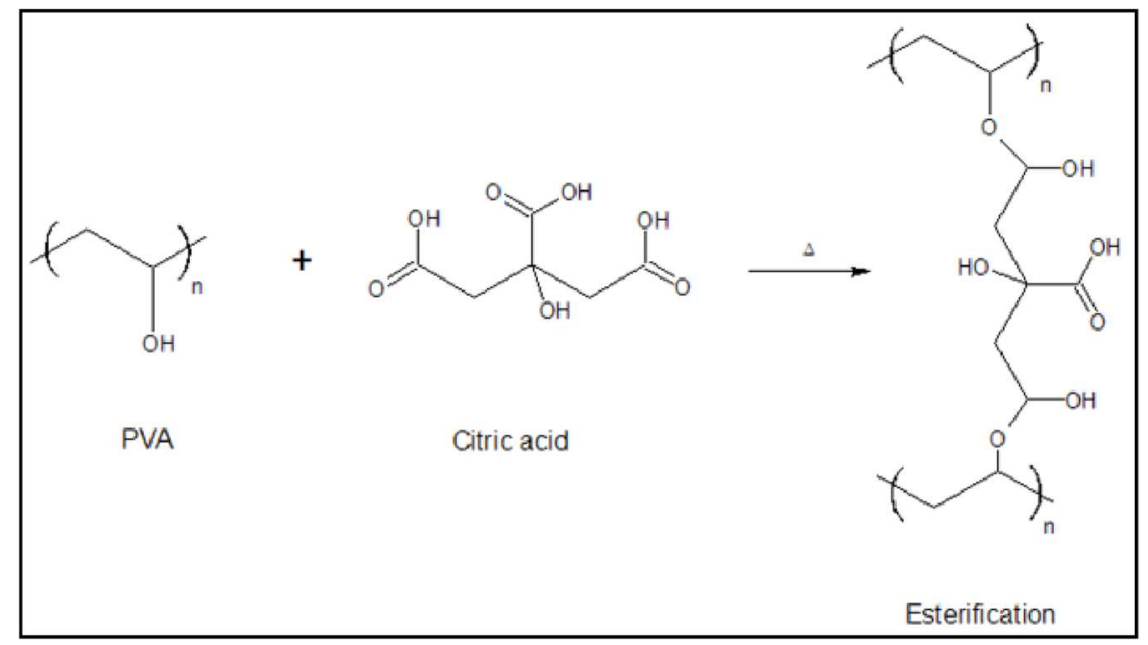

Source: Adapted from Pang et al., 2011.

The development and optimization of the crosslinking process can be realized by a design of experiments (DOE) method. This approach stands out as a result of its execution simplicity and the reduced number of experiments needed. The results obtained can be subsequently analyzed by the response surface methodology (RSM), which is used to determine the best parameters to achieve a specific purpose (MONTGOMERY, 2018).

In view of all these facts, the main goal of this work was to evaluate the swelling of PVA membranes produced by varying the citric acid concentration and the time and temperature of crosslinking. Through this study, we intended to determine the preparation method that provides the smallest swelling of the membrane. The optimization of the process was realized by DOE and the results were analyzed by RSM. The optimized membrane had the characteristics needed to be subsequently applied in the pharmaceutical removal from hospital wastewater. 


\section{Experimental section}

\subsection{Materials}

PVA $(84,000 \mathrm{kDa}, 88 \%$ hydrolysis) and glycerol (analytical grade) were purchased from Vetec Química Fina, while anhydrous citric acid (analytical grade) was acquired from Cinética Química.

\subsection{Synthesis of silver nanoparticles}

Silver nanoparticles (AgNPs) were synthesized according to previous work (RAOTA et al., 2019). Briefly, the synthesis was realized by the combination of equal volumes of an aqueous solution of silver nitrate $\left(2.5 \mathrm{mmol} \mathrm{L}^{-1}\right)$ and a grape pomace (Bordô cultivar) hydroalcoholic extract $\left(50 \mathrm{~g} \mathrm{~L}^{-1}, \mathrm{pH}=10.0\right)$ at room temperature.

\subsection{Design of experiments}

The design of experiments (DOE) was performed by $2^{3}$ experimental planning with a central point (MONTGOMERY, 2018). This methodology was chosen due to its execution simplicity and the reduced number of experiments required. Table 1 shows the combinations of time, temperature, and citric acid concentration applied to the nine assays realized. Each experiment was carried out in four replicates.

Table 1 - DOE performed in this work

\begin{tabular}{cccc} 
Experiment & Time (h) & Temperature $\left({ }^{\circ} \mathbf{C}\right)$ & Concentration $(\%, \mathbf{m} / \mathbf{v})$ \\
\hline 1 & 2 & 110 & 10 \\
2 & 2 & 110 & 30 \\
3 & 2 & 130 & 10 \\
4 & 2 & 130 & 30 \\
5 & 4 & 110 & 10 \\
6 & 4 & 110 & 30 \\
7 & 4 & 130 & 10 \\
8 & 4 & 130 & 30 \\
9 & 3 & 120 & 20 \\
\hline
\end{tabular}




\subsection{Membrane preparation}

Initially, an aqueous PVA solution $(15 \%, \mathrm{~m} / \mathrm{v})$ was prepared through polymer dissolution in distilled water $\left(80^{\circ} \mathrm{C}\right)$ under continuous stirring for $24 \mathrm{~h}$.

The membranes were produced by the methodology of casting of the polymeric solution. Three solutions were prepared containing $10 \%, 20 \%$, and $30 \%(\mathrm{~m} / \mathrm{v})$ of citric acid (SHAMELI; AMERI, 2017), whereas the final concentrations of PVA $(12 \%, \mathrm{~m} / \mathrm{v}), \mathrm{AgNPs}(20 \%$, $\mathrm{v} / \mathrm{v})$, and glycerol $(4 \%, \mathrm{~m} / \mathrm{v})$ were kept constant. The final concentration of PVA, glycerol and AgNPs was established in relation of the total volume of the solution, while the citric acid amount was determined in relation to the PVA mass of the solution.

For the solution preparation, $35 \mathrm{~mL}$ of the PVA solution $(15 \%, \mathrm{~m} / \mathrm{v})$ were heated at $50{ }^{\circ} \mathrm{C}$ under continuous stirring. Subsequently, the amount of glycerol and citric acid was added into the solution, according to the DOE. After 30 min of vigorous stirring, the AgNPs were included and the mixture was stirred for $5 \mathrm{~min}$. The solution was then rested for 20 min for bubble removal.

Later, $5 \mathrm{~mL}$ of the mixture were casted in a Petri dish coated with poly(tetrafluoroethylene) (area of $91.6 \mathrm{~cm}^{2}$ ). The solutions were casted uniformly on the dishes and the membranes were left at room temperature for $\sim 24 \mathrm{~h}$ for solvent evaporation. After the dry step, the membranes were removed from the Petri dishes and cut into $2.0 \mathrm{~cm}$ long squares.

\subsection{Crosslinking reaction}

The crosslinking reaction was realized in an air circulation oven (DeLeo, model AGSEDT). The membranes were placed on a poly(tetrafluoroethylene) sheet and put in the oven, with the time and temperature defined according to the DOE.

\subsection{Swelling calculation}

At the end of the crosslinking reaction, the membranes were left in a desiccator for $24 \mathrm{~h}$. They were then weighed and measured using a precision scale (Marte, model AD500) and a digital caliper (Digimess, $150 \mathrm{~mm}$ ). Later, the membranes were immersed in distilled 
water for $24 \mathrm{~h}$ at room temperature $\left(23^{\circ} \mathrm{C}\right)$. At the end of this procedure, the excess of water was carefully removed and the membranes were weighted and measured again. The mass and dimensional swelling were calculated using Eqs. (1) and (2), respectively (PANG et al., 2011):

$$
\begin{gathered}
\Delta_{\text {mass }}=\frac{m_{w e t}-m_{d r y}}{m_{d r y}} \\
\Delta_{\text {area }}=\frac{a_{w e t}-a_{d r y}}{a_{d r y}}
\end{gathered}
$$

where $\Delta_{\text {mass }}$ is the mass variation of the membrane, $m_{\text {wet }}$ is the mass of the membrane after hydration (in g), $m_{d r y}$ is the mass of the dry membrane (in g), $\Delta_{\text {area }}$ is the dimensional variation of the membrane, $a_{w e t}$ is the area of the membrane after hydration (in $\mathrm{cm}^{2}$ ) and $a_{d r y}$ is the area of the dry membrane (in $\mathrm{cm}^{2}$ ).

\subsection{Statistical analysis}

The data obtained through swelling calculations were analyzed using Statistica 13. Initially, the data were normalized and the variance analysis (ANOVA) was performed. Finally, the response surface images were generated.

\subsection{Membrane characterization}

\subsubsection{Fourier-transform infrared (FT-IR) spectroscopy}

The FT-IR characterization (Thermo Scientific, model Nicolet iS10A) was performed with an attenuated total reflectance accessory. Before analysis, the membranes were left in a desiccator for $24 \mathrm{~h}$. The spectra were collected in the range of 4000 to $400 \mathrm{~cm}^{-1}$, with 128 scans and a nominal resolution of $2.0 \mathrm{~cm}^{-1}$, in percentual transmittance mode.

2.8.2 Scanning electron microscopy coupled with a field emission gun (SEM-FEG) 
For the SEM-FEG characterization (Tescan, model MIRA3), the membranes were prepared by cryogenic fracture, placed on a stub with carbon tape, and metalized with a thin layer of gold for $30 \mathrm{~s}$ in a 0.13 mbar vacuum to perform the analysis. The acceleration tension was $5.0 \mathrm{kV}$, with magnifications between 500 and $5000 \times$.

\subsubsection{Water contact angle (WCA)}

The WCA assay was realized by the sessile drop method. The membranes were fixed on a flat surface, $100 \mu \mathrm{L}$ of distilled water was placed in the membrane and photographs were taken. The images were posteriorly analyzed using Surftens for the determination of the angle between the water drop and the surface of the membrane.

\section{Results and Discussion}

\subsection{Statistical analysis}

\subsubsection{Swelling calculation}

Table 2 shows the results of mass and dimensional swelling, obtained by Eqs. (1) and (2). As can be seen, the membranes with the lowest swelling values were crosslinked for $4 \mathrm{~h}$ at $130{ }^{\circ} \mathrm{C}$ (experiments 7 and 8). 
Table 2 - Mass and dimensional swelling results of the evaluated membranes

\begin{tabular}{cccccccc}
\hline \multirow{2}{*}{ Experiment } & Time & Temperature & Concentration & \multicolumn{2}{c}{$\begin{array}{c}\text { Dimensional } \\
\text { swelling }\end{array}$} & \multicolumn{2}{c}{$\begin{array}{c}\text { Mass } \\
\text { swelling }\end{array}$} \\
& $\mathbf{( h )}$ & $\left.\mathbf{(}{ }^{\circ} \mathbf{C}\right)$ & $(\mathbf{\%}, \mathbf{m} / \mathbf{v})$ & Average & SD & Average & SD \\
\hline 1 & 2 & 110 & 10 & 1.22 & 0.16 & 3.41 & 0.68 \\
2 & 2 & 110 & 30 & 0.77 & 0.02 & 1.58 & 0.07 \\
3 & 2 & 130 & 10 & 0.35 & 0.04 & 0.92 & 0.03 \\
4 & 2 & 130 & 30 & 0.32 & 0.04 & 0.61 & 0.15 \\
5 & 4 & 110 & 10 & 1.20 & 0.06 & 2.94 & 0.03 \\
6 & 4 & 110 & 30 & 0.63 & 0.01 & 1.11 & 0.05 \\
7 & 4 & 130 & 10 & 0.24 & 0.01 & 0.42 & 0.01 \\
8 & 4 & 130 & 30 & 0.16 & 0.05 & 0.45 & 0.06 \\
9 & 3 & 120 & 20 & 0.36 & 0.01 & 0.65 & 0.04 \\
\hline
\end{tabular}

Note: SD = standard deviation .

\subsubsection{Variance analysis}

Figures 2 and 3 show the Pareto diagrams for dimensional and mass swelling, respectively. The Pareto diagrams quantify the effect of each factor and the interaction between them in the membrane swelling. The variance analysis revealed that the factors of time, temperature, and citric acid concentration, as well as the combination of temperature and concentration effects, had a significant effect on the membrane swelling $(p<0.05)$. Conversely, the combination of time and temperature, as well as time and concentration, did not have a significant effect on the result. For both dimensional and mass swelling, the temperature was the factor with the highest influence, followed by the citric acid concentration, the combination between concentration and temperature, and finally time. 
Figure 2 - Pareto diagram of dimensional swelling of the evaluated membranes

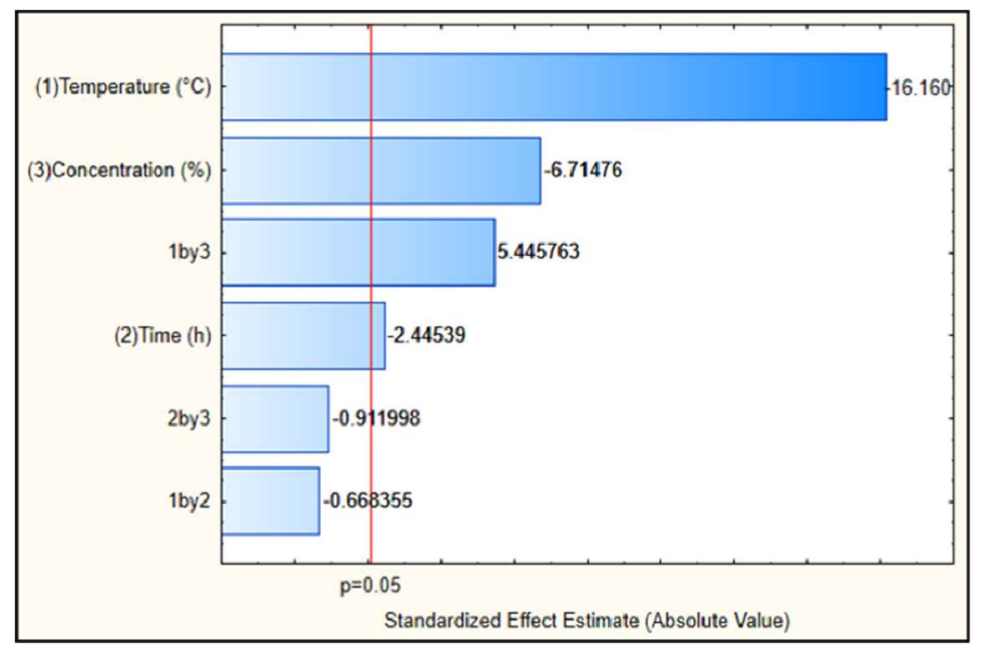

Figure 3 - Pareto diagram of mass swelling of the evaluated membranes

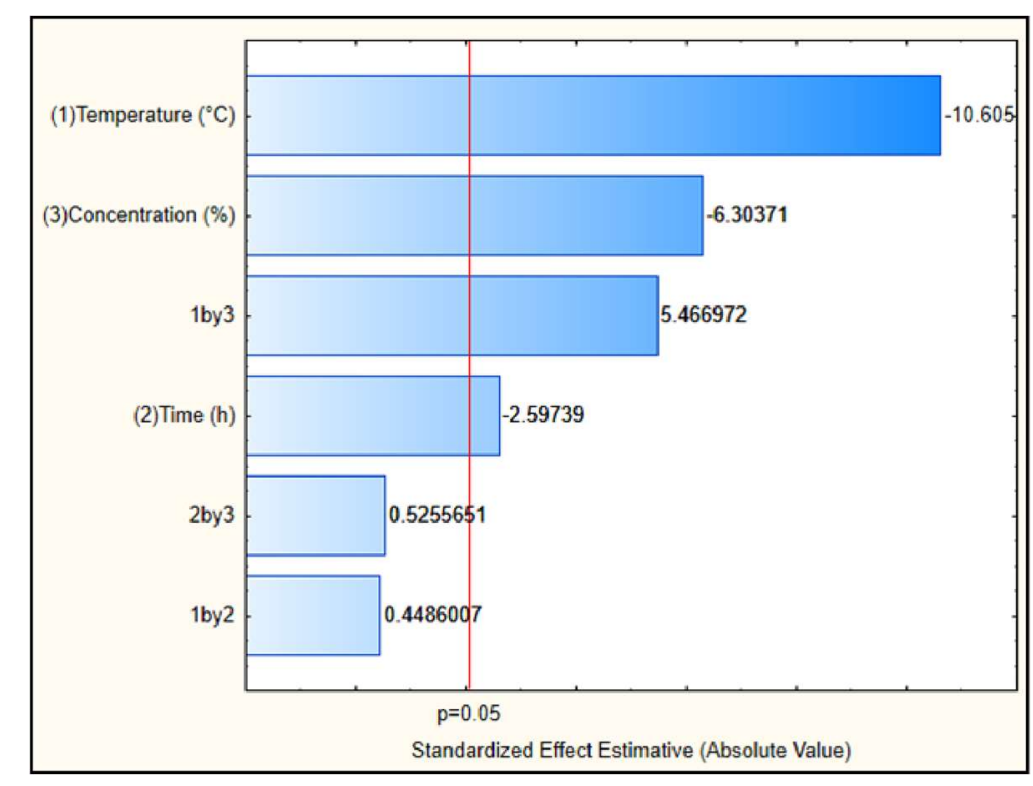

\subsubsection{Analysis of RSM images}

Figure 4 presents the RSM image of the effects of temperature and time in the dimensional swelling of the membrane. As can be seen, the increase in temperature significantly reduces the dimensional swelling, while for the time factor, this effect is less significant. The same behavior was observed for mass swelling. Therefore, the lowest swelling was obtained with the highest temperature and time values $\left(4 \mathrm{~h}\right.$ and $\left.130^{\circ} \mathrm{C}\right)$.

Figure 4-RSM of temperature and time effects in the dimensional swelling of the evaluated membranes 


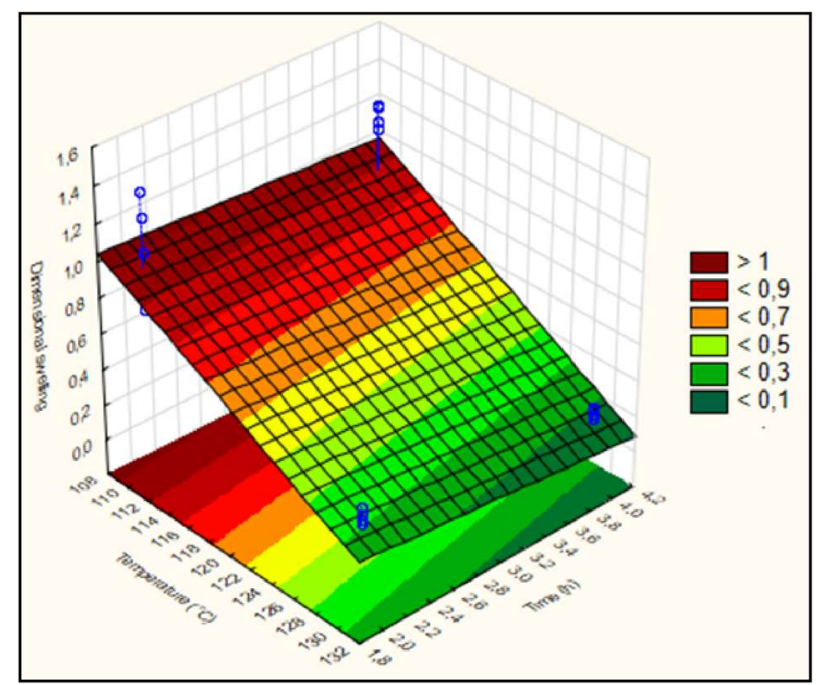

Figure 5 shows the response surface image of the effects of time and concentration in the dimensional swelling of the membranes. As can be observed, these two factors negatively affect the dimensional swelling, and the time effect is less significant. The same behavior was observed for mass swelling.

Figure 5 - Response surface of time and concentration effects in the dimensional swelling of the evaluated membranes

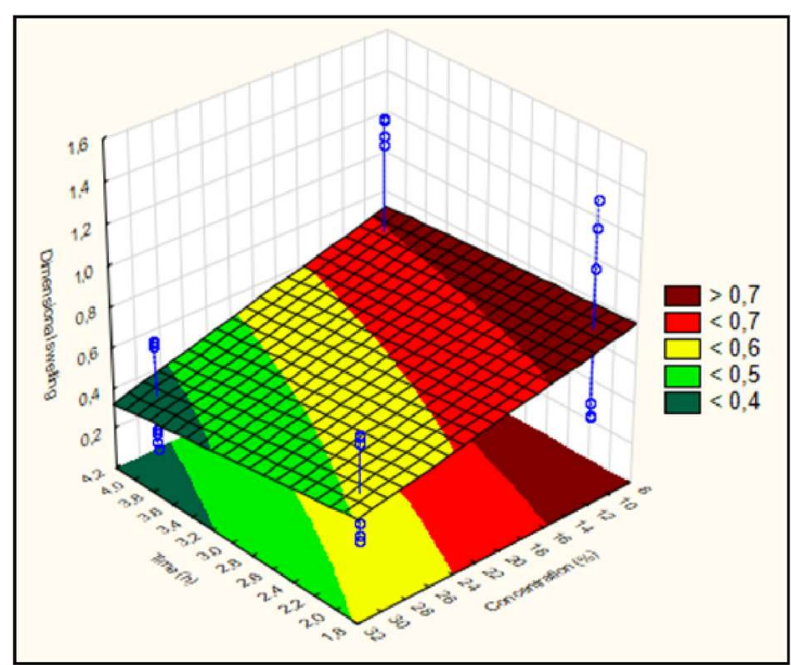

Figure 6 presents the response surface image of the effects of temperature and concentration in the mass swelling of the membranes. It is observed that the increase in both factors causes a reduction in swelling and the temperature effect was the most significant. As the temperature increases, the citric acid concentration effect appears to be less significant. The same behavior was observed for dimensional swelling. 
Figure 6 - Response surface of temperature and concentration effects in the mass swelling of the evaluated membranes

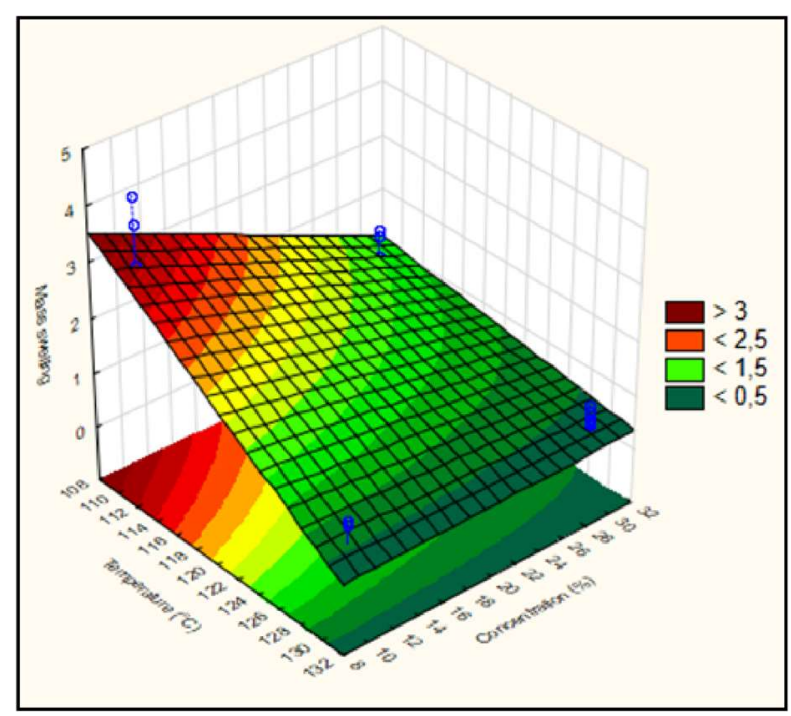

An overall analysis of the response surfaces shows that the temperature had a major influence in the swelling behavior and the lowest value occurred at $130^{\circ} \mathrm{C}$. In contrast, the time showed a smaller effect and the best condition at $130{ }^{\circ} \mathrm{C}$ was obtained in $4 \mathrm{~h}$. On this basis, the characterization assays were performed to choose the ideal citric acid concentration, since the results of the response surfaces were not conclusive.

\subsection{Membrane characterization}

\subsubsection{FT-IR analysis}

The statistical analysis showed the time as the factor of larger effect on the membrane swelling. For this reason, the FT-IR analysis was performed only for the membranes crosslinked for $4 \mathrm{~h}$, in all the combinations of temperature and citric acid concentration (experiments 5, 6, 7, and 8).

Figure 7 shows the FT-IR spectra of the membranes crosslinked for $4 \mathrm{~h}$. The band at $3348 \mathrm{~cm}^{-1}$ is related to the $\mathrm{O}-\mathrm{H}$ stretching, while the $\mathrm{C}-\mathrm{H}$ stretching was observed at 2910 $\mathrm{cm}^{-1}$; both groups are associated with the PVA chain. The $\mathrm{C}=\mathrm{O}$ stretching observed at 1710 $\mathrm{cm}^{-1}$ can be considered an indication of the crosslinking through the esterification reaction between the hydroxyls from PVA and the carbonyls from the citric acid (SHAMELI; AMERI, 
2017). Likewise, Mansor et al. (2020) reported $C=O$ stretching as an indication of the crosslinking in the PVA/CA membrane. The esterification is also supported by the band at $1230 \mathrm{~cm}^{-1}$, which is related to the ester C-O stretching (PANG et al., 2011).

In order to verify the effect of the temperature in the swelling behavior, the ratio between the band area related to the $\mathrm{O}-\mathrm{H}$ and $\mathrm{C}-\mathrm{H}$ stretching of the membranes crosslinked at $110{ }^{\circ} \mathrm{C}$ and $130{ }^{\circ} \mathrm{C}$ was measured. A reduction of $14.5 \%$ in the $\mathrm{O}-\mathrm{H}$ stretching band area was observed with increasing temperature. This behavior indicates a reduction in the number of hydroxyl groups as a result of the esterification reaction.

Figure 7 - FT-IR spectra of the membranes crosslinked for $4 \mathrm{~h}$

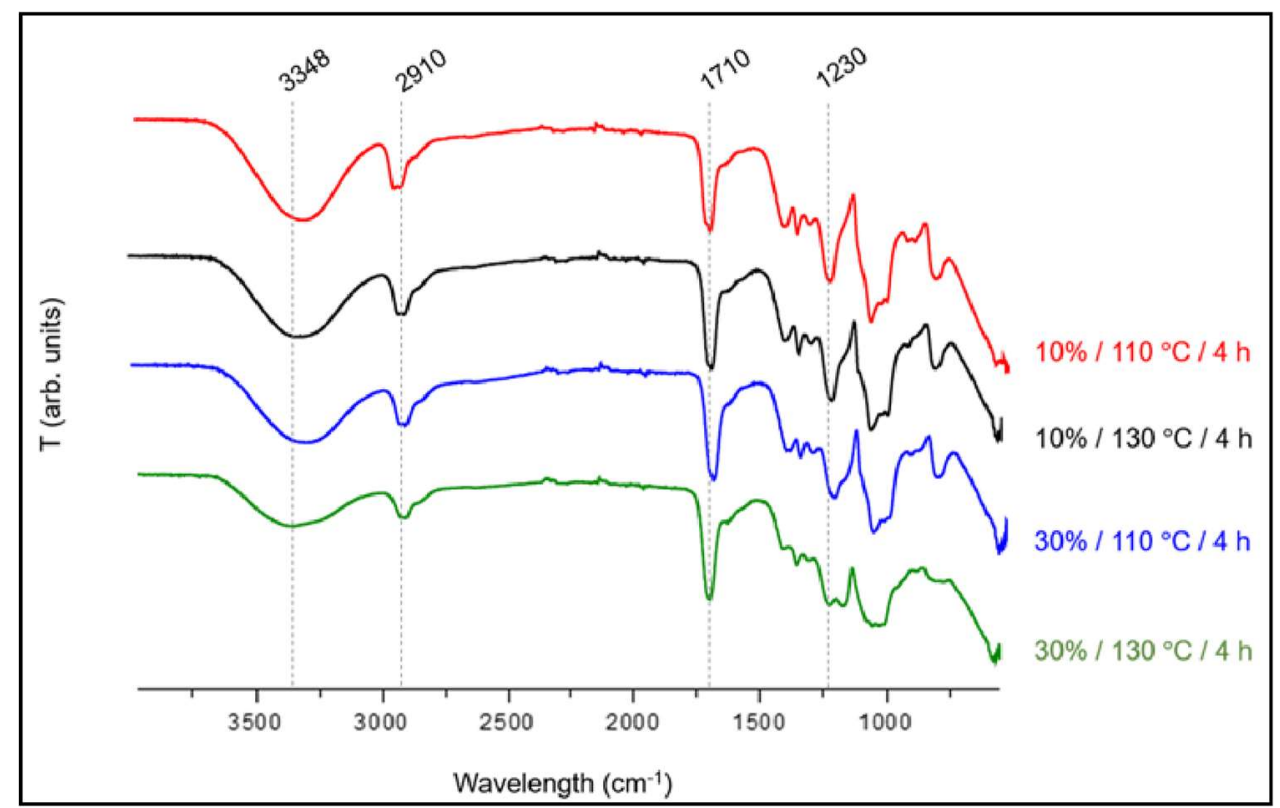

\subsubsection{WCA analysis}

Figure 8 presents the results of the WCA analysis for the membranes crosslinked for $4 \mathrm{~h}$ at $130^{\circ} \mathrm{C}$. It is well known that the contact angle is an indication of the membrane affinity for water, and a WCA value higher than $90^{\circ}$ characterizes a hydrophobic surface (LAZGHAB et al., 2005). The membranes maintained their hydrophilic character after crosslinking $\left(\sim 80^{\circ}\right)$, but in a more attenuated manner. In comparison, the PSf/PVA membrane produced by Guo et al. (2019) demonstrated $\sim 80 \%$ of sodium sulfate rejection with a contact angle of 71.6. $6^{\circ}$ The PSf-PVA-montmorillonite membrane produced by Bojnourd and Pakizeh (2018) showed a contact angle between $60.61^{\circ}$ and $56.04^{\circ}$, depending on the amount of 
montmorillonite added to the membrane. Permeation analysis revealed that the membranes with a lower contact angle promoted a higher rejection rate against cephalexin and amoxicillin. Thus, the next tests employed the membrane with $10 \%$ of citric acid because it had a minor contact angle.

Figure 8 - Images of the WCA assay of the membranes crosslinked for $4 \mathrm{~h}$ at $130^{\circ} \mathrm{C}$

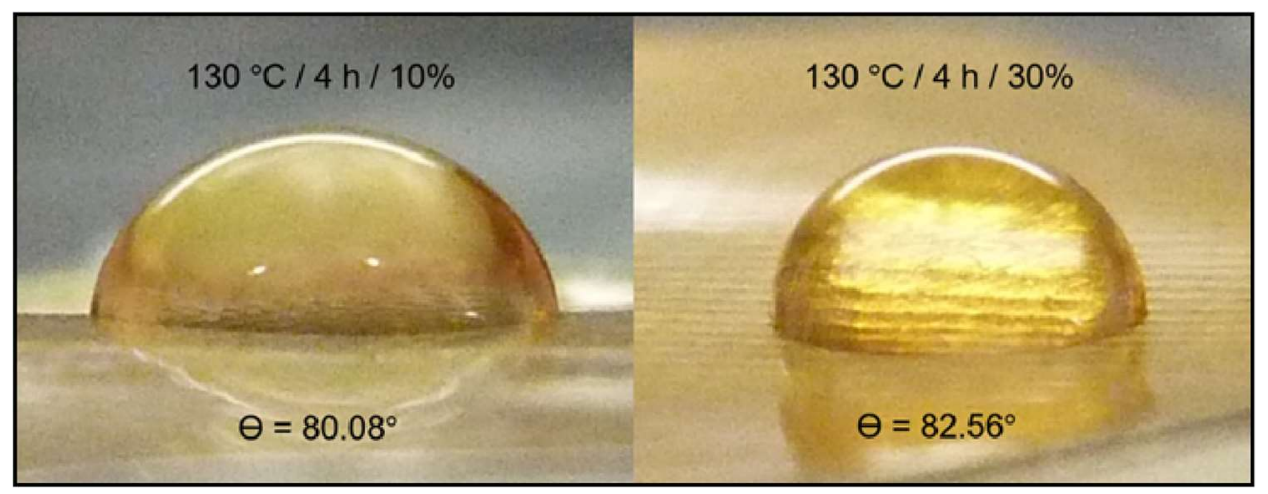

\subsubsection{SEM-FEG analysis}

The SEM-FEG images of membrane $7\left(130^{\circ} \mathrm{C}, 4 \mathrm{~h}\right.$, and 10\%) in Figure 9 show a smooth and dense surface. There are a few pores, probably produced by the bubbles that remained during the membrane preparation. The cross-section has distinct regions; the bottom section is dense and has inclined streaks, possibly arising from the casting method used. The top section, on the contrary, seems to be denser, but with the presence of particulate matter. The total thickness of the membrane was measured at $113 \mu \mathrm{m}$. Similar results were found by Guo et al. (2019), in which the crosslinked PVA appears to be a dense layer on the PSf membrane surface.

Figure 9 - Images of membrane $7\left(130^{\circ} \mathrm{C}, 4 \mathrm{~h}\right.$, and $\left.10 \%\right)$ obtained by SEM-FEG. On the left-hand side, the surface image; on the right-hand side, the cross-section image 


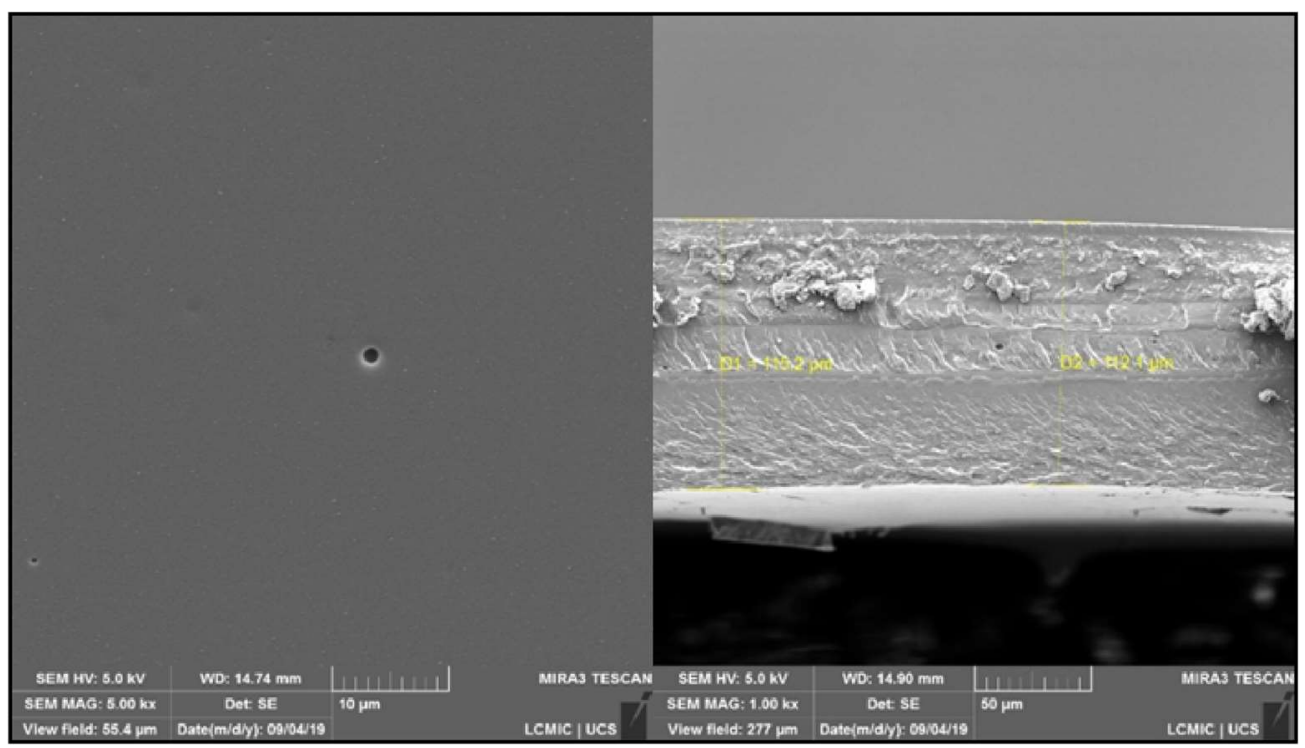

\section{Conclusions}

The preparation process of the membranes was optimized through DOE with analysis by RSM. The membrane with the best performance was obtained with $10 \%$ of citric acid and crosslinked for $4 \mathrm{~h}$ at $130^{\circ} \mathrm{C}$. In these conditions, the membrane had a mass swelling of $42 \%$ and a dimensional swelling of $24 \%$. The characterization also showed that an esterification reaction was responsible for the crosslinking, resulting in a smooth and dense hydrophilic membrane. In conclusion, it was possible to prepare a PVA-based membrane with suitable characteristics for its future application in pharmaceutical removal from hospital wastewater.

\section{Acknowledgments}

This work was supported by the Coordenação de Aperfeiçoamento de Pessoal de Nível Superior (CAPES - Finance Code 001) through the scholarship PROSUC and by the Fundação de Amparo à Pesquisa do Estado do Rio Grande do Sul (FAPERGS) through the scholarship PROBIC-FAPERGS.

\section{References}


BOJNOURD, Fatemeh Medhat; PAKIZEH, Majid. Preparation and characterization of a nanoclay/PVA/PSf nanocomposite membrane for removal of pharmaceuticals from water. Appl. Clay Sci. 2018;(162):326-338.

BOLTO, Brian; TRAN, Thuy; HOANG, Manh; XIE, Zongli. Crosslinked poly (vinyl alcohol) membranes. Prog. Polym. Sci. 2009;34(9):969-981.

GUO, Miao; WANG, Shuhao; GU, Kaifeng; SONG, Xiaoxiao; ZHOU, Yong; GAO, Congjie. Gradient cross-linked structure: towards superior PVA nanofiltration membrane performance. J. Membr. Sci. 2019;(569):83-90.

HOSSEINZADEH, Hossein. Synthesis and swelling properties of a poly (vinyl alcohol)-based superabsorbing hydrogel. Curr. Chem. Lett. 2013;2(3):153-158.

LAZGHAB, Mariem; SALEH, Khashayar; PEZRON, Isabelle; GUIGON, Pierre; KOMUNJER, Ljepsa. Wettability assessment of finely divided solids. Powder Technol. 2005;157(1-3):7991.

MANSOR, Eman S.; ABDALLAH, Heba; SHABAN, A.M.. Fabrication of high selectivity blend membranes based on poly vinyl alcohol for crystal violet dye removal. J. Environ. Chem. Eng. 2020;8(3):103706-103719.

MIAROV, Olga; TAL, Alon; AVISAR, Dror. A critical evaluation of comparative regulatory strategies for monitoring pharmaceuticals in recycled wastewater. J. Environ. Manage. 2020;(254):109794-109806.

MONTAGNER, Cassiana; SODRÉ, Fernando; ACAYABA, Raphael; VIDAL, Cristiane; CAMPESTRINI, Iolana; LOCATELLI, Marco; et al. Ten years-snapshot of the occurrence of emerging contaminants in drinking, surface and ground waters and wastewaters from São Paulo State, Brazil. J. Braz. Chem. Soc. 2019;30(3):614-632.

MONTGOMERY. C; RUNGER, George C. Estatística aplicada e probabilidade para engenheiros. Translated by Verônica Calado - 6. ed. - Rio de Janeiro: LTC, 2018.

OECD. Pharmaceutical residues in freshwater: Hazards and policy responses. Paris, 2019.

OLIVEIRA, Milina de; FRIHLING, Breno Emanuel Farias; VELASQUES, Jannaina; MAGALHÃES FILHO, Fernando Jorge Corrêa; CAVALHERI, Priscila Sabioni; MIGLIOLO, Ludovico. Pharmaceuticals residues and xenobiotics contaminants: occurrence, analytical techniques and sustainable alternatives for wastewater treatment. Sci. Total Environ. 2020;(705).

OUYANG, Zhiyu; HUANG, Zhonghua; TANG, Xinyuan; XIONG, Caihua; TANG, Mengdi; LU, Yuting. A dually charged nanofiltration membrane by $\mathrm{pH}$-responsive polydopamine for pharmaceuticals and personal care products removal. Sep. Purif. Technol. 2019;(211):90-97. 
NADOUR, Meriem; BOUKRAA, Fatima; BENABOURA, Ahmed. Removal of diclofenac, paracetamol and metronidazole using a carbon-polymeric membrane. J. Environ. Chem. Eng. 2019;7(3):103080-103092.

PANG, Suh Cem; CHIN, Suk Fun; TAY, Soon Hiang; TCHONG, Fui Mui. Starch-maleatepolyvinyl alcohol hydrogels with controllable swelling behaviors. Carbohydr. Polym. 2011;84(1):424-429.

PRAPTOWIDODO, Veronica S. Influence of swelling on water transport through PVA-based membrane. J. Mol. Struct. 2005;739(1-3):207-212.

RAICOPOL, Matei D.; ANDRONESCU, Corina; VOICU, Stefan I.; VASILE, Eugeniu; PANDELE, Andreea M. Cellulose acetate/layered double hydroxide adsorptive membranes for efficient removal of pharmaceutical environmental contaminants. Carbohydr. Polym. 2019;(214):204212.

RAOTA, Camila Suliani; CERBARO, Aline Fagundes; SALVADOR, Mirian; DELAMARE, Ana Paula Longaray; ECHEVERRIGARAY, Sergio; CRESPO, Janaina da Silva; et al. Green synthesis of silver nanoparticles using an extract of Ives cultivar (Vitis labrusca) pomace: characterization and application in wastewater disinfection. J. Environ. Chem. Eng. 2019;7(5):103383-103392.

SHAMELI, Aslan; AMERI, Elham. Synthesis of cross-linked PVA membranes embedded with multi-wall carbon nanotubes and their application to esterification of acetic acid with methanol. Chem. Eng. J. 2017;(309):381-396.

VERAS, Tatiane Barbosa; PAIVA, Anderson Luiz Ribeiro de; DUARTE, Marta Maria Menezes Bezerra; NAPOLEÃO, Daniela Carla; CABRAL, Jaime Joaquim da Silva Pereira. Analysis of the presence of anti-inflammatories drugs in surface water: a case study in Beberibe river - PE, Brazil. Chemosphere. 2019;(222):961-969.

VIOTTI, P. V. Diclofenac removal from water by adsorption on Moringa oleifera pods and activated carbon: Mechanism, kinetic and equilibrium study. J. Cleaner Prod. 2019;(219):809817. 